\title{
GENETIC STRUCTURE OF DIFFERENT CAT POPULATIONS IN EUROPE AND SOUTH AMERICA AT A MICROGEOGRAPHIC LEVEL: IMPORTANCE OF THE CHOICE OF AN ADEQUATE SAMPLING LEVEL IN THE ACCURACY OF POPULATION GENETICS INTERPRETATIONS
}

\author{
Manuel Ruiz-Garcia
}

\begin{abstract}
The phenotypic markers, coat color, pattern and hair length, of natural domestic cat populations observed in four cities (Barcelona, Catalonia; Palma Majorca, Balearic Islands; Rimini, Italy and Buenos Aires, Argentina) were studied at a microgeographical level. Various population genetics techniques revealed that the degree of genetic differentiation between populations of Felis catus within these cities is relatively low, when compared with that found between populations of other mammals. Two different levels of sampling were used. One was that of "natural" colonies of cat families living together in specific points within the cities, and the other referred to "artificial" subpopulations, or groups of colonies, inhabiting the same district within a city. For the two sampling levels, some of the results were identical: 1) little genic heterogeneity, 2) existence of panmixia, 3) similar levels of expected heterozygosity in all populations analyzed, 4) no spatial autocorrelation, with certain differentiation in the Buenos Aires population compared to the others, and 5) very high correlations between colonies and subpopulations with the first factors from a $Q$ factor analysis. Nevertheless, other population genetic statistics were greatly affected by the differential choice of sampling level. This was the case for: 1) the amount of heterogeneity of the $F_{S T}$ and $G_{S T}$ statistics between the cities, which was greater at the subpopulation level than at colony level, 2) the existence of correlations between genic differentiation statistics and size variables at subpopulation level, but not at the colony level, and 3) the relationships between the genetic variables and the principal factors of the $R$ factorial analysis. This suggests that care should be taken in the choice of the sampling unit, for inferences on population genetics to be valid at the microgeographical level.
\end{abstract}

\section{INTRODUCTION}

Population genetics studies of domestic cat (Felis catus) populations based on the observation of the allele frequencies of certain morphological characteristics such as the coat color and tabby character, hair length and some skeletal abnormalities began with Searle (1949), and since then, more than 400 cat populations have been analyzed worldwide from this point of view. Studies attempting to explain the possible genetic structure of cat populations at a microgeographical sampling level within a city are however much more recent (Ruiz-Garcia, 1988, 1989, 1991; 1993; 1994, 1997, 1998a,b,c; Ruiz-Garcia and Klein, 1997). The main aims of this study conducted exclusively with feral cats were: 1) to analyze the possible causes underlying the present spatial distribution and gene frequency variance between cities which have different historical, demographic and ecological characteristics, which might have affected the genetic structure and evolution of their cat populations, or whether the genetic structure of the populations of this species is primarily defined by their highly promiscuous reproductive behavior, independently of the different environmental characteristics between dif-

Unidad de Genetica (Biologia Evolutiva), Departamento de Biologia, Facultad de Ciencias, Pontificia Universidad Javeriana, CRA 7A, No. 4382, Bogota DC, Colombia, and CIGEEM, Avd. Virgen Montserrat, $2076^{\circ}$ $1^{A}$, Barcelona, 08041, Spain.E-mail mruiz@javercol.javeriana.edu.co ferent cities (Liberg and Sandell, 1988; Natoli and De Vito, 1988). The cities chosen for the microgeographical genetic analysis were: Barcelona and Palma Majorca (Iberian Peninsula and Balearic Islands, Spain, Europe), Rimini (Italy, Europe), and Buenos Aires (Argentina, South America). The three European populations represent the original range of distribution of domestic cats over the last 2000 years, whereas the cat population of Buenos Aires is much more recent (no more than 400 years) and is thought of as being originated from the European populations included in this analysis. 2) The second aim was to determine whether the results obtained from the analysis of cat colonies, being the colony the minimum unit of observation for population genetics sake, as the author considers, differed to any extent from observations obtained from the analysis of a higher level of population organization, such as were the groups of colonies or subpopulations defined by the researcher. In this way, it was possible to assess whether the choice of a non-representative sampling level could lead to invalid conclusions. The colony sampling level therefore was defined as: cats observed at fixed locations, with many phylopatric feral female lineages inhabiting a small range, clearly separated from other such populations by short geographical distances $(500 \mathrm{~m}$ to $2 \mathrm{~km}$, approximately). The subpopulation sampling level was defined as: groups of colonies inhabiting neighboring areas in a given district within a city, with neighboring areas sharing characteristics corresponding to the same "urban habitats", and whose time of construction was of the same epoch. For a subpopulation to be regarded as such, there 
were no important geographical constraints for the natural flow of the animals within the area, for example, important avenues with heavy traffic. This sampling level is probably highly artificial, but it was used as an instrument in order to demonstrate the importance of the choice of the most correct unit, for the sake of population biology. As will be shown here, some of the results differ in relation to the sampling level chosen. It must be born in mind, however, that it is often difficult to determine the real population unit in nature. 3) The third aim was to see whether there is a relationship between the degree of genetic heterogeneity between the microgeographical sampling levels analyzed, and some of the demographic parameters of human and cat populations in these cities.

This study analyzed whether there were significant levels of correlation between various population genetics statistics, and the size of the human populations involved. A justification of selecting human population size as a demographic variable is the existence of a strong correlation between the density of owned cats and humans (Todd, 1977), so that the larger the human population, the larger the absolute size of the cat population, since there would be a larger number of potential human cat owners (owned cat subcomponent), as well as the higher the possibilities of habitats being generated which could be used by the felids (feral cat subcomponent). With this assumptions in mind, the largest total cat population should be that of Buenos Aires (metropolitan area: 10.796.036 people; directly sampled area covering about 2.900 .000 inhab), followed by Barcelona (metropolitan area: 3.975.000; directly sampled area covering about 2.000.000), Palma Majorca (metropolitan area: 400.000; directly sampled area covering about 310.000 ), and Rimini (about 150.000). The colony and subpopulation mean size of the samples obtained for the populations studied was also used as a demographic variable for the following reason: a demographic and census investigation was carried out in parallel from 1987 to 1992 in those areas sampled for coat allele frequencies, and about 50\% of the cats sampled for color coat genes were applied colored collars coded with numbers around their necks. The results on the population size estimates for the colonies and for the "artificial" subpopulations analyzed were directly related to the sample sizes presented in this work, for all colonies and "subpopulations" in the four cities studied ( $\mathrm{r}=0.87$, average correlation coefficient for the four cities). Therefore, the size of the sample size at the colony and subpopulation level was used as a representative variable of the real size of the colonies and subpopulations.

\section{MATERIAL AND METHODS}

The data analyzed was compiled between 1987 and 1995, having defined two population sampling levels within the cities. At the colony sampling level the num- bers of colonies in this study were: Barcelona, 11 colonies; Palma Majorca, 10 colonies; Rimini, 11 colonies, and Buenos Aires, 7 colonies. At the subpopulation sampling level (occasionally a colony might coincide with a subpopulation): 5 in Barcelona, 6 in Palma Majorca, 6 in Rimini, and 4 in Buenos Aires. In every case an inequivocal recognition of each individual was attained due to the thorough registration of the phenotypic characteristics, as well as a complete photographic record of each animal, which allowed the post-analysis of the observations made during each journey. Demographic census methods used in order to reveal the relation between the population sizes of the sampled areas and the genetic structure were as follows. The first method was developed by Darroch (1958), and attributes an equal likelihood of marking any individual of the population, irrespective of its sex, age, or particular difference of behavior of the individuals, i.e. aggressivity, etc. (Pollock, 1981). The expression used was

$$
\left(1-\left(\mathrm{M}_{\mathrm{S}+1} / \mathrm{N}\right)\right)=\left(1-\left(\mathrm{n}_{\mathrm{i}} / \mathrm{N}\right)\right)
$$

where $\mathrm{M}_{\mathrm{S}+1}$ is the total number of different cats marked in $\mathrm{S}$ sampling sessions, $\mathrm{n}_{\mathrm{i}}$ is the number of cats sampled in each session, and $\mathrm{N}$ is the population size estimated in the area analyzed. Two other methods were used, which assumed a closed population in each area investigated (Caughley, 1977).

The method of Chapman (1951) uses the expression:

$$
\mathrm{N}=[((\mathrm{M}+1)(\mathrm{n}+1)) /(\mathrm{m}+1)]-1
$$

with $\operatorname{var}(\mathrm{N})=[(\mathrm{M}+1)(\mathrm{n}+1)(\mathrm{M}-\mathrm{m})(\mathrm{n}-\mathrm{m}) /$

$$
\left[(\mathrm{m}+1)^{2}(\mathrm{~m}+2)\right]
$$

where $\mathrm{M}$ is the number of cats marked in a first sample, $\mathrm{n}$ is the number of cats sampled a second time in the same area, and $m$ is the number of cats marked previously and observed during the second session.

The method of Bailey (1951) as revised by Seber (1982) was especially usefull for the type of data obtained. The mathematic expression is:

$$
\mathrm{N}=[\mathrm{M}(\mathrm{n}+1) /(\mathrm{m}+1)]
$$

with $\operatorname{var}(\mathrm{N})=\left[\mathrm{M}^{2}(\mathrm{n}+1)(\mathrm{n}-\mathrm{m}) /\left[(\mathrm{m}+1)^{2}(\mathrm{~m}+2)\right]\right.$

The last method employed was the triple capture method (Bailey, 1951, 1952), created for evaluating population sizes in open populations, where

$$
\mathrm{N}_{2}=\left(\mathrm{M}_{1}^{\prime} \cdot \mathrm{n}_{2}\right) / \mathrm{m}_{12} \text { and } \mathrm{M}_{1} / \mathrm{M}_{2}=\mathrm{m}_{13} / \mathrm{m}_{23}
$$

where $M_{1}^{\prime}=\left(M_{2} \cdot m_{13}\right) / m_{23}$ obtaining, then

$$
\mathrm{N}_{2}=\mathrm{M}_{2} \mathrm{~m}_{13} \mathrm{n}_{2} /\left(\mathrm{m}_{12}-\mathrm{m}_{23}\right)
$$


with $\operatorname{var}(\mathrm{N})=\mathrm{N}_{2}{ }^{2}\left[\left(1 / \mathrm{m}_{12}\right)+\left(1 / \mathrm{m}_{23}\right)-\left(1 / \mathrm{m}_{13}\right)-\left(1 / \mathrm{n}_{2}\right)\right]$ and modified for small samples by Southwood (1978):

$$
\mathrm{N}_{2}=\left[\mathrm{M}_{2} \cdot \mathrm{m}_{13}\left(\mathrm{n}_{2}+1\right)\right] /\left[\left(\mathrm{m}_{12}+1\right)\left(\mathrm{m}_{23}+1\right)\right]
$$

with $\operatorname{var}(\mathrm{N})=\left[\mathrm{M}_{2}^{2}\left(\mathrm{n}_{2}+1\right)\left(\mathrm{n}_{2}+2\right)\left(\mathrm{m}_{13}-1\right) \mathrm{m}_{13}\right] /$ $\left[\left(\mathrm{m}_{12}+1\right)\left(\mathrm{m}_{12}+2\right)\left(\mathrm{m}_{23}+1\right)\left(\mathrm{m}_{23}+2\right)\right]$

Each area was sampled in three occasions, and the procedure of applying collars to individuals was performed in two of them. In the equations, $M_{1}$ represents the number of cats marked in the first sampling session, $M_{2}$ the number of cats marked in the second sampling session, and $n_{2}$ and $n_{3}$ the number of individuals recorded in the second and third sampling sessions, respectively. Additionally, $\mathrm{m}_{12}$ is defined as the number of cats which, having been marked in the first session, were observed in the second session; $\mathrm{m}_{13}$ is the number of cats marked in the first session, which were observed in the third session, and $\mathrm{m}_{23}$ is the number of cats marked in the second sampling session and observed in the third sampling session. For a review, see Tellerias (1986). The different population sizes in each area sampled were very similar for the different methods used. On average, these values were highly correlated with the sample sizes for the study of coat allele frequencies $(r=0.87)$.

Cat phenotypes were recorded directly after observing the animals, and the genetic nomenclature used is in agreement with the Committee on Standardized Genetic Nomenclature for Cats (1968). The 7 unlinked genetic characteristics studied here included the sex-linked character $\underline{\mathrm{O}}(\underline{\mathrm{O}}, \underline{\mathrm{o}}$; orange vs. non-orange), and six autosomal characters: $\underline{\mathrm{A}}$ ( $\underline{\mathrm{A}}, \underline{\mathrm{a}}$; agouti vs. non-agouti), $\underline{\mathrm{T}}\left(\underline{\mathrm{T}}^{\mathrm{A}}, \underline{\mathrm{t}}^{ \pm}, \underline{\mathrm{t}}_{-}\right.$; Abyssinian vs. mackerel or stripped vs. blotched tabby), $\underline{\mathrm{D}}$ ( $\underline{\mathrm{D}}, \underline{\mathrm{d}}$; full color vs. dilution), $\underline{\mathrm{L}}$ ( $\underline{\mathrm{L}}, \underline{\mathrm{l}}$; short hair vs. long hair), $\underline{S}(\underline{S}, \underline{\text { s}}$; piebald white spotting vs. non-piebald white spotting), and $\underline{\mathrm{W}}$ ( $\underline{\mathrm{w}}, \mathrm{W}$; non-dominant white vs. dominant white). Inheritance of these factors has been previously discussed in detail by Robinson (1977) and Wright and Walters (1982). The $\mathrm{p}(\underline{\mathrm{O}})$ frequency has been calculated using the maximum likelihood formulae of Robinson and Silson (1969) and Robinson (1972). Assuming a sex ratio $1: 1, \mathrm{p}(\underline{\mathrm{O}})=(2 \mathrm{a}+\mathrm{b}) / 2 \mathrm{~N}$, where $\mathrm{a}=$ number of orange $(\mathrm{O} /$ $\mathrm{O}$ and $\mathrm{O} /-), \mathrm{b}=$ number of tortoiseshell phenotypes $(\mathrm{O} / \mathrm{o})$, and $\mathrm{N}=$ total sample size. For autosomal loci, recessive frequencies (q) were taken as the square root of observed phenotype frequencies, while dominant frequencies $(p)$ were taken as $1-\mathrm{q}$.

The Hardy-Weinberg equilibrium was studied, for the $\mathrm{O}$ locus at both the colony and subpopulation sampling levels, using a G-test.

Nei's (1973) genic diversity analysis at both sampling population levels was performed using the statistics $\mathrm{G}_{\mathrm{ST}}$ (genetic differentiation between subpopulations relative to the total population), and $\mathrm{G}_{\mathrm{CT}}$ (genetic differentiation between colonies relative the total population). The statistic $\mathrm{F}_{\mathrm{ST}}$, (one of the F-Wright for genetic heterogeneity corrected for sampling sizes; Wright, 1951,1965) was also obtained. All these statistics were calculated using weighed mean and variances (Workman and Niswander, 1970).

The mean expected heterozygosity $(\mathrm{H})(\mathrm{Nei}, 1978)$ was studied in the colonies and subpopulations in order to detect the possible importance of stochastic processes such as genetic drift (e.g., Nygren and Rasmusson, 1980; RuizGarcia, 1994).

The spatial autocorrelation analysis described in Sokal and Oden (1978a,b) and Ruiz-Garcia and Jordana $(1997 a, b)$ was applied to the genetical characteristics studied at a subpopulation level. Only this sampling level was used since the sample sizes were maximum, and the standard deviation of allele frequencies the lowest.

\section{Computation of the autocorrelation coefficients and correlograms}

Two statistics were used in order to evaluate spatial autocorrelation: the Moran's I statistic, and Geary's c coefficient (see Sokal and Oden, 1978a). The connection matrix employed is binary due to the difficulty in postulating reasonable weights in this study (Gabriel and Sokal, 1969; Sokal and Oden, 1978b; Trexler, 1988). Three distance classes (DC) were defined at the subpopulational level (only 2 DC were defined for the Buenos Aires subpopulation due to the small number of related pairs of localities in these distance classes). The upper geographical limit for the defined DC were: Barcelona: 4,348, 5,290 and 7,352 m; Palma Majorca: 2,708, 4,881 and 12,965 m; Rimini: 1,690, 3,265 and 7,184 m, and Buenos Aires: 4,438 and $10,196 \mathrm{~m}$. All these particular geographical distances were chosen so as to optimize the allocation of locality pairs (an equal number of point pairs) for each distance class. To determine the statistical significance of autocorrelation coefficients, the Bonferroni procedure (Oden, 1984) was used.

A factorial analysis of allele frequencies was performed ( $\mathrm{R}$ type). The first factor explains the most total variance. The amount of variance explained diminishes with each of the remaining factors (Maxwell, 1977; Harris, 1985). The eigenvalues of each variable could be seen as proportional to a percentage of the total variability explained by the factor. The Kaiser's rule (Kaiser, 1960) was applied to the results, and only those factors whose eigenvalues were higher than one were chosen. A "scree plot" was also used to choose the significant eigenvalues (Cattell, 1966). The following analyses were also performed: the Bartlett's sphericity test to analyze whether the correlation matrix was an identity matrix, the KaiserMeyer-Olkin index in order to compare observed correlation coefficient values with partial correlation coefficient values, and the MSA index (measure of sampling adequacy). In this study the iterative principal factor was used. Varimax and oblique rotations were also used (Harris, 1985), and their results are not shown since they were 
the same. Finally, correlations at each locality and the first two factors (Q type) were determined and submitted to a spatial autocorrelation analysis to observe whether there was substantial differentiation in the spatial distribution of these correlations in the cat populations studied at the subpopulation level.

\section{RESULTS}

The genetic profiles of the cat populations analyzed at colony and subpopulation levels of sampling are shown in Table I. No significant differences were detected in the Hardy-Weinberg equilibrium for the $\mathrm{O}$ locus at both sampling levels in the cities studied (Table II), there being no difference between the colony and subpopulation levels in this regard.

\section{Colony sampling level}

The mean sample sizes of the colonies were $64.45 \pm$ 17.72 (Barcelona), $46.40 \pm 12.91$ (Palma Majorca), 46.54 \pm 11.84 (Rimini), and 54.28 \pm 22.40 (Buenos Aires). Sample values had a similar range. Geographic mean distances between the respective colony pairs were 4,212, 3,780, 3,176 and 4,930 $\mathrm{m}$ (Barcelona, Palma Majorca, Rimini and Buenos Aires, respectively). The $\mathrm{F}_{\mathrm{CT}}$ and $\mathrm{G}_{\mathrm{CT}}$ statistics showed that 95 to $97 \%$ of the total genetic variability is found within the colonies. Barcelona and Rimini showed intercolonial differentiation estimates slightly lower than the other two populations although with no statistical differentiation (value range: 0.0307-0.0428). No significant correlation was observed between genetic differentiation statistics and the two demographic variables studied.

Table I - Genetic profiles of natural domestic cat colonies and subpopulations studied in Barcelona (Iberian), Palma Majorca (Balearic Islands), Rimini (Italy) and Buenos Aires (Argentina) for seven loci. N $=$ Sample size $. \mathrm{O}=$ orange; $\mathrm{a}=$ non-agouti; $\mathrm{t}^{\mathrm{b}}=$ blotched tabby; $\mathrm{d}=$ dilution; $1=$ long hair; $\mathrm{S}=$ white spotting; $\mathrm{W}=$ dominant white.

\begin{tabular}{|c|c|c|c|c|c|c|c|c|}
\hline Locus & $\mathrm{N}$ & $\mathrm{O}$ & $\mathrm{a}$ & $\mathrm{t}^{\mathrm{b}}$ & $\mathrm{d}$ & 1 & $S$ & W \\
\hline \multicolumn{9}{|l|}{ Barcelona } \\
\hline A & 64 & 0.238 & 0.733 & 0.368 & 0.218 & 0.125 & 0.193 & 0.008 \\
\hline B1 & 31 & 0.274 & 0.645 & 0.000 & 0.365 & 0.000 & 0.281 & 0.000 \\
\hline B2 & 66 & 0.138 & 0.713 & 0.338 & 0.175 & 0.000 & 0.266 & 0.000 \\
\hline B3 & 82 & 0.123 & 0.684 & 0.298 & 0.314 & 0.110 & 0.263 & 0.006 \\
\hline $\mathrm{C}$ & 50 & 0.100 & 0.668 & 0.327 & 0.316 & 0.000 & 0.383 & 0.000 \\
\hline D1 & 39 & 0.128 & 0.676 & 0.309 & 0.320 & 0.000 & 0.284 & 0.000 \\
\hline D2 & 61 & 0.100 & 0.675 & 0.246 & 0.183 & 0.129 & 0.225 & 0.000 \\
\hline E1 & 34 & 0.250 & 0.650 & 0.000 & 0.250 & 0.000 & 0.441 & 0.000 \\
\hline E2 & 30 & 0.074 & 0.650 & 0.420 & 0.333 & 0.322 & 0.333 & 0.035 \\
\hline E3 & 143 & 0.198 & 0.744 & 0.119 & 0.307 & 0.170 & 0.232 & 0.000 \\
\hline E4 & 109 & 0.131 & 0.682 & 0.294 & 0.167 & 0.136 & 0.257 & 0.005 \\
\hline \multicolumn{9}{|c|}{ Palma Majorca } \\
\hline A & 27 & 0.135 & 0.866 & 0.333 & 0.277 & 0.192 & 0.412 & 0.019 \\
\hline B & 30 & 0.167 & 0.694 & 0.408 & 0.483 & 0.000 & 0.270 & 0.000 \\
\hline $\mathrm{C} 1$ & 58 & 0.114 & 0.694 & 0.402 & 0.375 & 0.263 & 0.173 & 0.009 \\
\hline $\mathrm{C} 2$ & 34 & 0.176 & 0.539 & 0.200 & 0.242 & 0.000 & 0.214 & 0.000 \\
\hline $\mathrm{C} 3$ & 28 & 0.500 & 0.866 & 0.365 & 0.423 & 0.423 & 0.018 & 0.000 \\
\hline $\mathrm{C} 4$ & 37 & 0.162 & 0.707 & 0.295 & 0.329 & 0.285 & 0.212 & 0.000 \\
\hline D1 & 113 & 0.252 & 0.726 & 0.430 & 0.357 & 0.352 & 0.284 & 0.000 \\
\hline D2 & 55 & 0.139 & 0.756 & 0.385 & 0.333 & 0.234 & 0.230 & 0.009 \\
\hline $\mathrm{E}$ & 35 & 0.220 & 0.732 & 0.000 & 0.297 & 0.000 & 0.233 & 0.014 \\
\hline $\mathrm{F}$ & 47 & 0.128 & 0.655 & 0.289 & 0.253 & 0.292 & 0.242 & 0.000 \\
\hline \multicolumn{9}{|l|}{ Rimini } \\
\hline A1 & 72 & 0.039 & 0.684 & 0.378 & 0.418 & 0.275 & 0.265 & 0.023 \\
\hline A2 & 75 & 0.169 & 0.637 & 0.390 & 0.417 & 0.267 & 0.339 & 0.007 \\
\hline B1 & 15 & 0.214 & 0.707 & 0.000 & 0.555 & 0.000 & 0.345 & 0.000 \\
\hline B2 & 75 & 0.148 & 0.718 & 0.424 & 0.295 & 0.263 & 0.186 & 0.007 \\
\hline B3 & 42 & 0.128 & 0.577 & 0.415 & 0.397 & 0.281 & 0.199 & 0.000 \\
\hline $\mathrm{C}$ & 39 & 0.158 & 0.718 & 0.387 & 0.397 & 0.000 & 0.239 & 0.000 \\
\hline D & 28 & 0.096 & 0.650 & 0.500 & 0.438 & 0.340 & 0.240 & 0.019 \\
\hline $\mathrm{E}$ & 30 & 0.278 & 0.798 & 0.408 & 0.385 & 0.000 & 0.230 & 0.000 \\
\hline F1 & 68 & 0.097 & 0.591 & 0.361 & 0.423 & 0.118 & 0.309 & 0.035 \\
\hline $\mathrm{F} 2$ & 34 & 0.078 & 0.775 & 0.000 & 0.440 & 0.183 & 0.339 & 0.000 \\
\hline F3 & 22 & 0.105 & 0.707 & 0.333 & 0.408 & 0.224 & 0.274 & 0.025 \\
\hline
\end{tabular}


Table I - Continued

\begin{tabular}{|c|c|c|c|c|c|c|c|c|}
\hline Locus & $\mathrm{N}$ & $\mathrm{O}$ & $\mathrm{a}$ & $t^{b}$ & d & 1 & S & $\mathrm{W}$ \\
\hline \multicolumn{9}{|c|}{ Buenos Aires } \\
\hline A & 47 & 0.096 & 0.783 & 0.343 & 0.386 & 0.412 & 0.188 & 0.000 \\
\hline B & 147 & 0.224 & 0.756 & 0.333 & 0.423 & 0.429 & 0.325 & 0.007 \\
\hline $\mathrm{C}$ & 34 & 0.409 & 0.774 & 0.447 & 0.348 & 0.454 & 0.478 & 0.015 \\
\hline D & 75 & 0.129 & 0.804 & 0.295 & 0.447 & 0.346 & 0.313 & 0.034 \\
\hline E & 34 & 0.029 & 0.664 & 0.000 & 0.297 & 0.420 & 0.252 & 0.000 \\
\hline F & 21 & 0.071 & 0.671 & 0.522 & 0.309 & 0.309 & 0.310 & 0.000 \\
\hline G & 22 & 0.095 & 0.806 & 0.000 & 0.534 & 0.477 & 0.383 & 0.023 \\
\hline \multicolumn{9}{|c|}{ Subpopulations } \\
\hline \multicolumn{9}{|c|}{ Barcelona } \\
\hline A & 64 & 0.238 & 0.733 & 0.368 & 0.218 & 0.125 & 0.193 & 0.008 \\
\hline B & 179 & 0.155 & 0.689 & 0.284 & 0.282 & 0.075 & 0.267 & 0.003 \\
\hline $\mathrm{C}$ & 50 & 0.100 & 0.668 & 0.327 & 0.316 & 0.000 & 0.389 & 0.000 \\
\hline $\mathrm{D}$ & 100 & 0.111 & 0.676 & 0.272 & 0.246 & 0.100 & 0.248 & 0.000 \\
\hline E & 316 & 0.169 & 0.705 & 0.233 & 0.263 & 0.171 & 0.269 & 0.005 \\
\hline \multicolumn{9}{|c|}{ Palma Majorca } \\
\hline A & 27 & 0.135 & 0.866 & 0.333 & 0.277 & 0.192 & 0.412 & 0.019 \\
\hline B & 30 & 0.167 & 0.694 & 0.408 & 0.483 & 0.000 & 0.270 & 0.000 \\
\hline $\mathrm{C}$ & 157 & 0.206 & 0.694 & 0.326 & 0.364 & 0.275 & 0.158 & 0.003 \\
\hline D & 173 & 0.216 & 0.736 & 0.415 & 0.351 & 0.318 & 0.262 & 0.003 \\
\hline $\mathrm{E}$ & 35 & 0.220 & 0.732 & 0.000 & 0.297 & 0.000 & 0.233 & 0.014 \\
\hline $\mathrm{F}$ & 47 & 0.128 & 0.655 & 0.289 & 0.253 & 0.292 & 0.242 & 0.000 \\
\hline \multicolumn{9}{|l|}{ Rimini } \\
\hline A & 147 & 0.108 & 0.661 & 0.385 & 0.417 & 0.271 & 0.304 & 0.015 \\
\hline B & 132 & 0.149 & 0.675 & 0.400 & 0.365 & 0.254 & 0.207 & 0.004 \\
\hline $\mathrm{C}$ & 39 & 0.158 & 0.718 & 0.387 & 0.397 & 0.000 & 0.239 & 0.000 \\
\hline $\mathrm{D}$ & 28 & 0.096 & 0.650 & 0.500 & 0.438 & 0.340 & 0.240 & 0.019 \\
\hline E & 30 & 0.278 & 0.798 & 0.408 & 0.385 & 0.000 & 0.230 & 0.000 \\
\hline F & 124 & 0.093 & 0.664 & 0.316 & 0.426 & 0.157 & 0.311 & 0.025 \\
\hline \multicolumn{9}{|c|}{ Buenos Aires } \\
\hline A & 228 & 0.224 & 0.765 & 0.351 & 0.406 & 0.429 & 0.314 & 0.007 \\
\hline B & 55 & 0.045 & 0.666 & 0.316 & 0.302 & 0.396 & 0.274 & 0.000 \\
\hline $\mathrm{C}$ & 75 & 0.129 & 0.804 & 0.295 & 0.447 & 0.346 & 0.313 & 0.034 \\
\hline $\mathrm{D}$ & 22 & 0.095 & 0.806 & 0.000 & 0.534 & 0.477 & 0.383 & 0.023 \\
\hline
\end{tabular}

\section{Subpopulation sampling level}

The average sample sizes of these subpopulations were $141.8 \pm 54.74$ (Barcelona), $77.33 \pm 33.20$ (Palma Majorca), $85.33 \pm 29.12$ (Rimini) and $95.00 \pm 45.66$ (Buenos Aires). Average geographical distances between all subpopulation pairs were 4,788, 5,361, 3,071, and 6,250 m (Barcelona, Palma Majorca, Rimini and Buenos Aires, respectively). The average area covered by these subpopulations were: 1.7885 in Barcelona, 0.5926 in Palma, 0.7659 in Rimini, and $0.6125 \mathrm{~km}^{2}$ in Buenos Aires. The analysis of $\mathrm{F}_{\mathrm{ST}}$, and $\mathrm{G}_{\mathrm{ST}}$ showed that by increasing the sample population level, the inter-subpopulational genetic differences were even lower than the equivalent at the colony level. An average subpopulation in Barcelona had $99.3 \%$ of the total genic diversity of the total population. For Palma Majorca this value was $97.7 \%$.

Lineal, logarithmic, exponential and power regression analyses were done for the $\mathrm{G}_{\mathrm{ST}}$ genetic heterogeneity statistic and the average geographical surface (AGS) of the subpopulations analyzed expressed in $\mathrm{km}^{2}$. The equations obtained were: for the lineal model, AGS $=-49.14407\left(\mathrm{G}_{\mathrm{ST}}\right)$ +1.7286 with $r=-0.7147$; for the logarithmic model, AGS $=-3.0065-0.9327 \ln \left(\mathrm{G}_{\mathrm{ST}}\right)$ with $\mathrm{r}=-0.8429$; for the exponential model, AGS $=-46.2364 \mathrm{e}^{1.763743(\mathrm{GST})}$ with $\mathrm{r}=-0.7431$, and for the power model, AGS $=0.02188\left(\mathrm{G}_{\mathrm{ST}}\right)^{-0.862059}$ with $\mathrm{r}$ $=-0.8609$. All $r$ coefficients were significantly negative.

In contrast with the values found at the colony level, significant correlations were detected between some of the genic statistics for the four populations studied, and for the two demographic variables (Table III). Two significant correlations were observed regarding sample size.

The expected mean heterozygosity levels at the colony and subpopulation sampling levels in the four populations showed very similar values. There were no significant differences when all the population means, at either colony or subpopulation level, were considered together (e.g., at colony level, Barcelona: H' = 4.9610 d.f. $0.90>$ P > 0.80; 
Table II - Hardy-Weinberg analysis of $\underline{\mathrm{O}}$ (orange) locus assuming a sex-ratio 1:1 with G-test (Sokal and Rohlf, 1981). This analysis is only shown for Rimini cat colonies and Barcelona, Palma Majorca, Rimini and Buenos Aires cat subpopulations. The Hardy-Weinberg analysis results for Barcelona, Palma Majorca and Buenos Aires cat colonies can be found elsewhere and were also in Hardy-Weinberg equilibrium. O/O $\& \mathrm{O} /-=$ Orange animals; $+/+\&+/-=$ non-orange animals; $\mathrm{O} /+=$ heterozygote females; $\mathrm{NS}=$ nonsignificant; SIG $=\mathrm{P}<0.05$.

\begin{tabular}{|c|c|c|c|c|c|c|c|c|}
\hline \multirow[t]{2}{*}{ Genotypes } & \multicolumn{3}{|c|}{ Observed } & \multicolumn{3}{|c|}{ Expected } & \multicolumn{2}{|c|}{ G-Test } \\
\hline & \multicolumn{3}{|c|}{$\mathrm{O} / \mathrm{O} \& \mathrm{O} /-\mathrm{O} /++++\&+/-$} & \multicolumn{3}{|c|}{$\mathrm{O} / \mathrm{O} \& \mathrm{O} /-\mathrm{O} /+++++\&+/-$} & & \\
\hline \multicolumn{9}{|c|}{ Rimini Colonies } \\
\hline A1 & 1 & 3 & 59 & 1.30 & 2.40 & 59.30 & $\mathrm{G}=0.214$ & NS \\
\hline A2 & 7 & 10 & 54 & 7.01 & 9.97 & 54.02 & $\mathrm{G}=0.000$ & NS \\
\hline B1 & 2 & 2 & 10 & 1.82 & 2.36 & 9.82 & $\mathrm{G}=0.077$ & NS \\
\hline B2 & 6 & 9 & 56 & 6.03 & 8.95 & 56.03 & $\mathrm{G}=0.000$ & NS \\
\hline B3 & 3 & 4 & 32 & 2.82 & 4.36 & 31.82 & $\mathrm{G}=0.042$ & NS \\
\hline $\mathrm{C}$ & 5 & 2 & 31 & 3.47 & 5.05 & 29.47 & $\mathrm{G}=3.065$ & NS \\
\hline D & 0 & 5 & 21 & 1.37 & 2.26 & 22.37 & $\mathrm{G}=5.290$ & SIG \\
\hline E & 5 & 5 & 17 & 4.79 & 5.42 & 16.79 & $\mathrm{G}=0.044$ & NS \\
\hline F1 & 4 & 5 & 58 & 3.56 & 5.87 & 57.57 & $\mathrm{G}=0.189$ & NS \\
\hline $\mathrm{F} 2$ & 2 & 1 & 31 & 1.43 & 2.45 & 30.12 & $\mathrm{G}=1.331$ & NS \\
\hline F3 & 1 & 2 & 16 & 1.11 & 1.79 & 16.10 & $\mathrm{G}=0.035$ & NS \\
\hline \multicolumn{9}{|c|}{ Barcelona Subpop } \\
\hline A & 9 & 12 & 42 & 9.28 & 11.42 & 42.29 & $\mathrm{G}=0.040$ & NS \\
\hline B & 15 & 25 & 137 & 15.88 & 23.22 & 137.90 & $\mathrm{G}=0.187$ & NS \\
\hline $\mathrm{C}$ & 2 & 6 & 42 & 2.75 & 4.50 & 42.75 & $\mathrm{G}=0.691$ & NS \\
\hline D & 7 & 8 & 84 & 6.11 & 9.78 & 83.11 & $\mathrm{G}=0.476$ & NS \\
\hline E & 32 & 39 & 234 & 30.09 & 42.79 & 232.12 & $\mathrm{G}=0.476$ & NS \\
\hline \multicolumn{9}{|c|}{ Palma Subpop } \\
\hline A & 2 & 3 & 21 & 1.98 & 3.03 & 20.99 & $\mathrm{G}=0.002$ & NS \\
\hline B & 3 & 4 & 23 & 2.92 & 4.16 & 22.92 & $\mathrm{G}=0.009$ & NS \\
\hline $\mathrm{C}$ & 21 & 23 & 112 & 19.63 & 25.73 & 110.64 & $\mathrm{G}=0.407$ & NS \\
\hline D & 25 & 22 & 120 & 21.88 & 28.24 & 116.87 & $\mathrm{G}=1.999$ & NS \\
\hline E & 6 & 3 & 25 & 4.57 & 5.84 & 23.58 & $\mathrm{G}=2.175$ & NS \\
\hline $\mathrm{F}$ & 4 & 4 & 39 & 3.38 & 5.23 & 38.39 & $\mathrm{G}=0.436$ & NS \\
\hline \multicolumn{9}{|c|}{ Rimini Subpop } \\
\hline A & 8 & 13 & 113 & 8.03 & 12.93 & 113.04 & $\mathrm{G}=0.000$ & NS \\
\hline B & 11 & 15 & 98 & 10.63 & 15.74 & 97.63 & $\mathrm{G}=0.047$ & NS \\
\hline $\mathrm{F}$ & 7 & 8 & 103 & 6.01 & 9.97 & 102.02 & $\mathrm{G}=0.581$ & NS \\
\hline \multicolumn{9}{|c|}{ B. Aires Subpop } \\
\hline A & 30 & 41 & 154 & 30.92 & 39.16 & 154.92 & $\mathrm{G}=0.113$ & NS \\
\hline B & 1 & 3 & 51 & 1.31 & 2.89 & 51.31 & $\mathrm{G}=0.225$ & NS \\
\hline $\mathrm{C}$ & 5 & 8 & 57 & 5.08 & 7.84 & 57.07 & $\mathrm{G}=0.007$ & NS \\
\hline D & 1 & 2 & 18 & 1.09 & 1.81 & 18.10 & $\mathrm{G}=0.030$ & NS \\
\hline
\end{tabular}

Table III - Correlation matrix (r) between gene differentiation and gene flow statistics of four cat populations at a subpopulation level with two demographic parameters, human population size (HPS) and median sample size (MSS). $\mathrm{F}_{\mathrm{ST}}$ (wright genetic differentiation statistic), $\mathrm{NmF}_{\mathrm{ST}}$ (gene flow from

the $\mathrm{F}_{\mathrm{ST}}$ statistic in an infinite island model), $\mathrm{NmF}_{\mathrm{ST} \alpha}$ (gene flow from the $\mathrm{F}_{\mathrm{ST}}$ statistic in an ndimensional island model), $\mathrm{G}_{\mathrm{ST}}$ (average Nei genic differentiation statistic), $\mathrm{G}_{\mathrm{ST}(\mathrm{D})}$ (direct Nei genic differentation statistic), $\mathrm{NmG}_{\mathrm{ST}}$ (gene flow from the $\mathrm{G}_{\mathrm{ST}}$ statistic in an infinite island model), $\mathrm{NmG}_{\mathrm{ST} \alpha}$ (gene flow from the $\mathrm{G}_{\mathrm{ST}}$ statistic in an n-dimensional island model).

\begin{tabular}{|llllllll|}
\hline & \multicolumn{1}{c}{$\mathrm{F}_{\text {ST }}$} & $\mathrm{NmF}_{\text {ST }}$ & $\mathrm{NmF}_{\text {ST } \alpha}$ & \multicolumn{1}{c}{$\mathrm{G}_{\text {ST }}$} & $\mathrm{G}_{\text {ST(D) }}$ & $\mathrm{NmG}_{\text {ST }}$ & $\mathrm{NmG}_{\text {ST } \alpha}$ \\
\cline { 2 - 7 } HPS & -0.5266 & 0.4390 & 0.2788 & -0.4985 & -0.4943 & 0.4082 & 0.2436 \\
MSS & -0.8660 & $0.9848^{*}$ & $0.9636^{*}$ & -0.8821 & -0.8073 & 0.8108 & 0.8700 \\
\hline
\end{tabular}

$* \mathrm{P}<0.05$ 
Palma Majorca: H' $=4.929$ d.f $.0 .90>$ P > 0.80; Rimini: $\mathrm{H}^{\prime}=3.4010$ d.f. $0.98>\mathrm{P}>0.95$; Buenos Aires: $\mathrm{H}^{\prime}=3.24$ 6 d.f. $0.80>\mathrm{P}>0.70$ ) (Table IV). All the values for mean heterozygosity were high in all the populations studied.

\section{Spatial autocorrelation analysis}

The correlograms in Figure 1 show all the spatial autocorrelation analysis applied to the four cat populations studied. As can be observed, the major part of the individual and average correlograms are not significant. No autocorrelation had been observed either at the colony level in a previous study (Ruiz-Garcia, 1998a).
The spatial autocorrelation analysis was applied to individual locality correlations of the two first Q factors from the four populations studied. Results were interesting at a subpopulation level (Figure 2). Only at this sampling level were differences detected between the populations studied. No differences were detected at a colony level (not shown here). Only Buenos Aires showed 100\% of the autocorrelation coefficients to be significant, with both correlograms (for the first and second factor) showing a clear monotonic clinal trend.

The factorial analyses indicated that in each city the relationships between the seven genetic variables and the principal factors were different (Table V). For instance,

Table IV - (A) Expected mean heterozygosity (H) and standard error (SE) for seven morphological loci at subpopulation level in the four cat populations studied. (B) Expected mean heterozygosity (H) and standard error (SE) for seven morphological loci at colony level in the four cat populations studied.

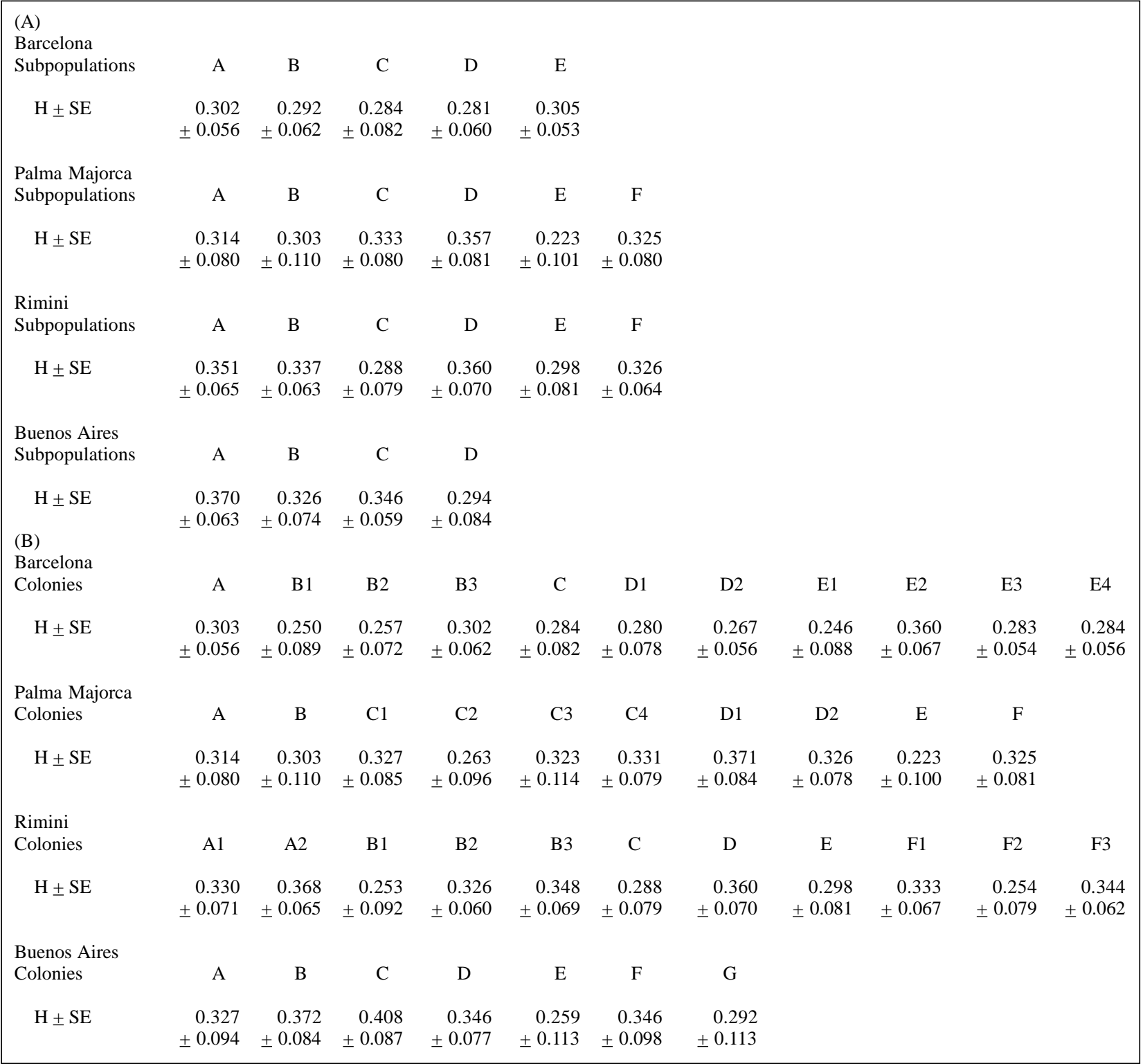


(A) Barcelona
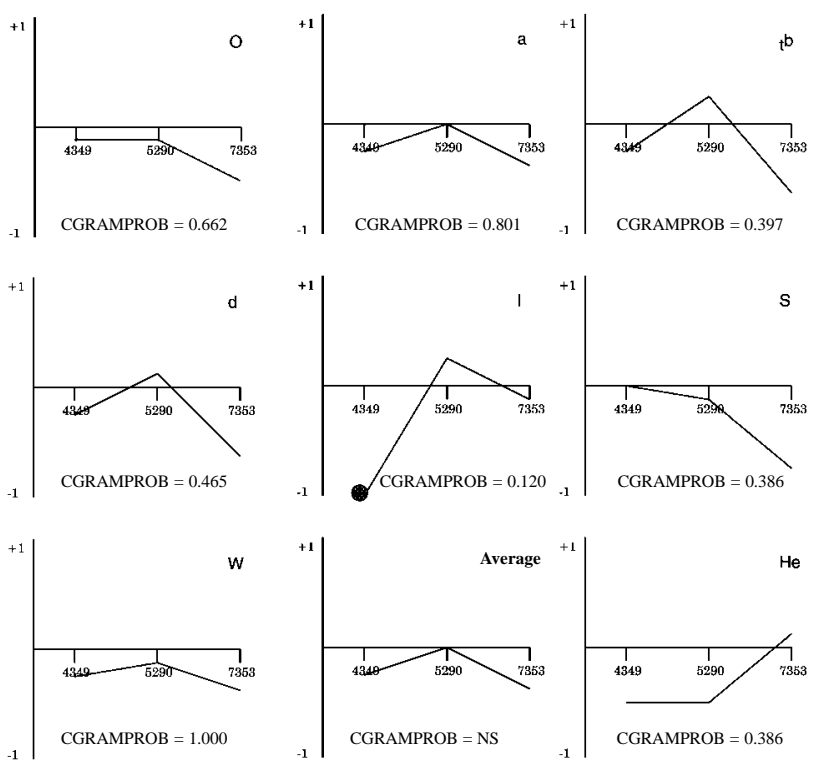

$\mathrm{P}<0.05$
(B) Palma Majorca
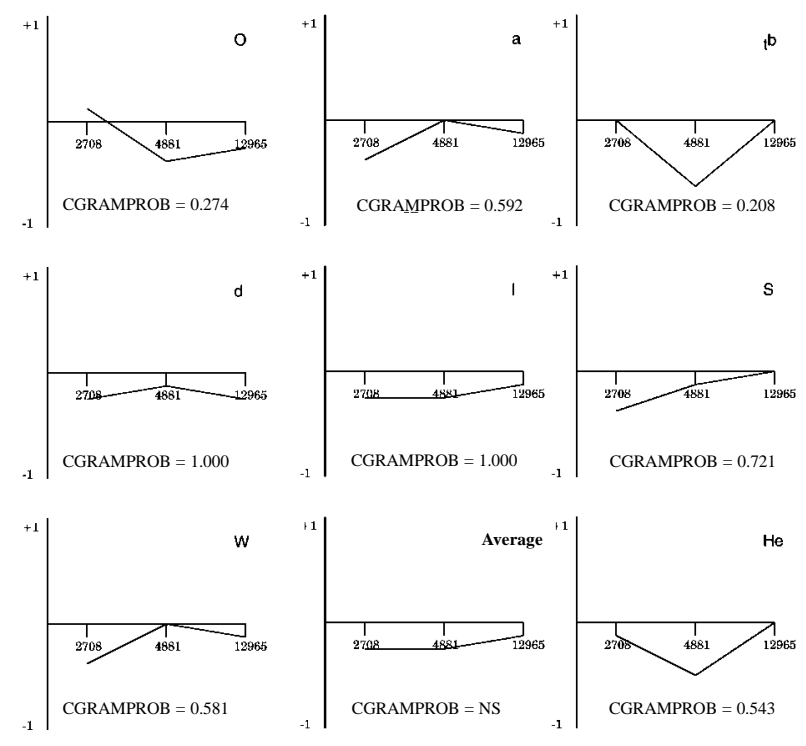

(C) Rimini
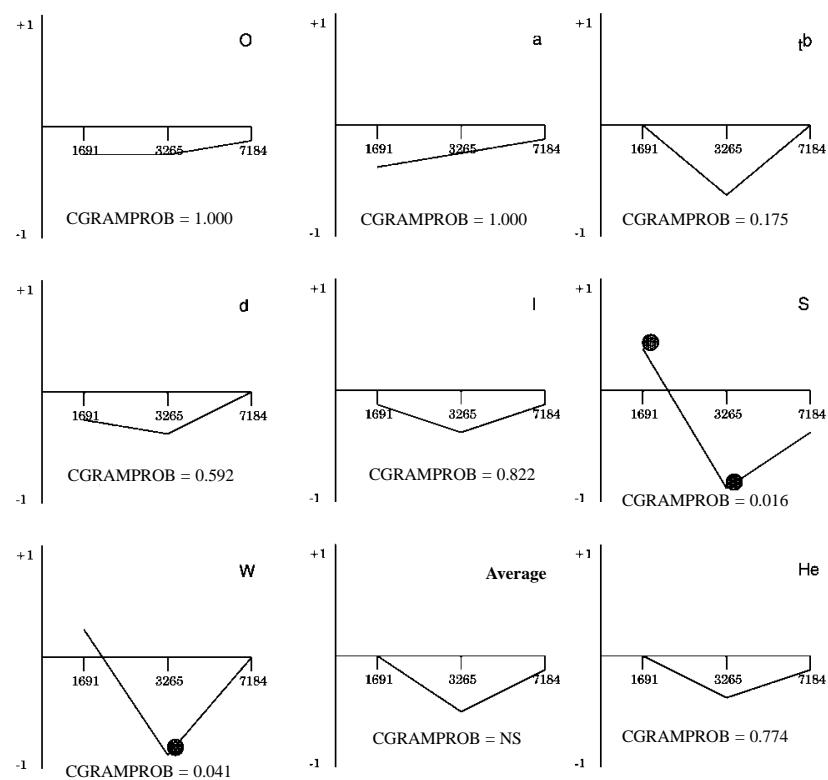

w
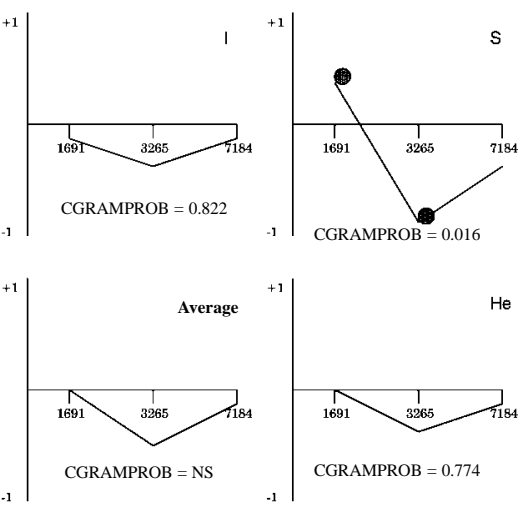

P $P<0.05$



(D) Buenos Aires
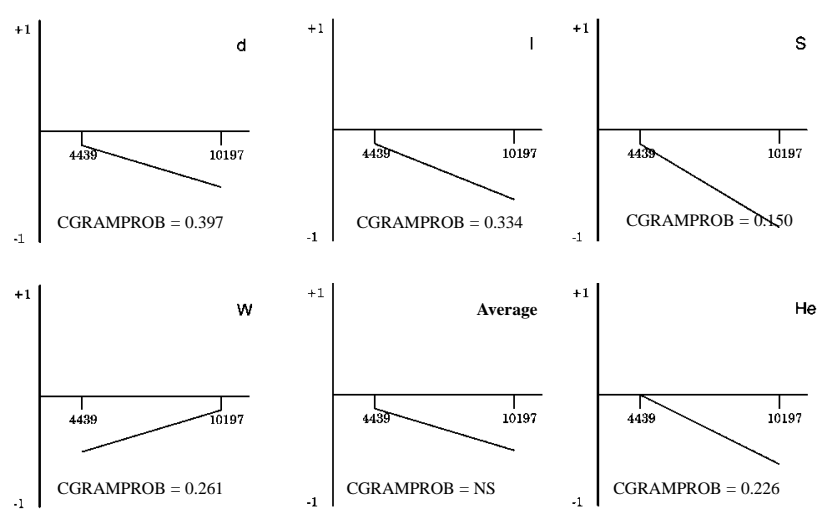

둥 $\mathrm{P}<0.05$

Figure 1 - Correlograms of the seven alleles analyzed $\left(\mathrm{O}=\right.$ orange, $\mathrm{a}=$ non-agouti, $\mathrm{t}^{\mathrm{b}}=$ blotched tabby, $\mathrm{d}=$ dilution, $\mathrm{l}=$ long hair, $\mathrm{S}=$ white spotting and $\mathrm{W}=$ dominant white) and of $\mathrm{He}$ (expected average heterozygosity). These correlograms were obtained with Moran's I index at subpopulation level with 3 distance classes (DC). (A) Barcelona; (B) Palma Majorca; (C) Rimini; (D) Buenos Aires. CGRAMPROB = Overall correlogram probability. NS = nonsignificant. 




\section{ubpopulation level}

(A) Barcelona

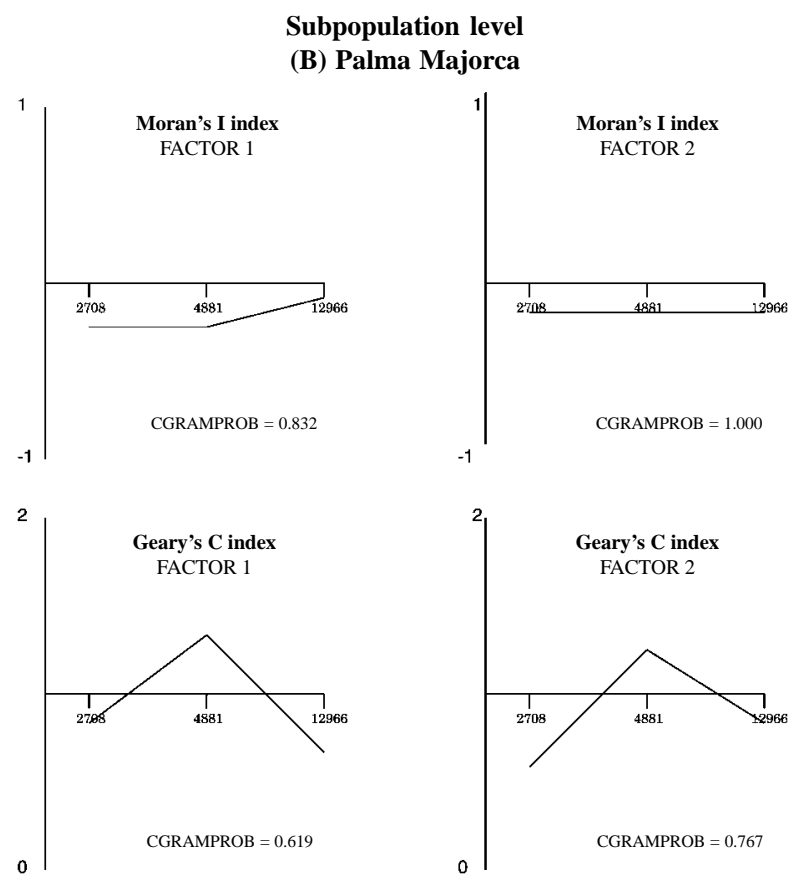

Subpopulation level

(C) Rimini

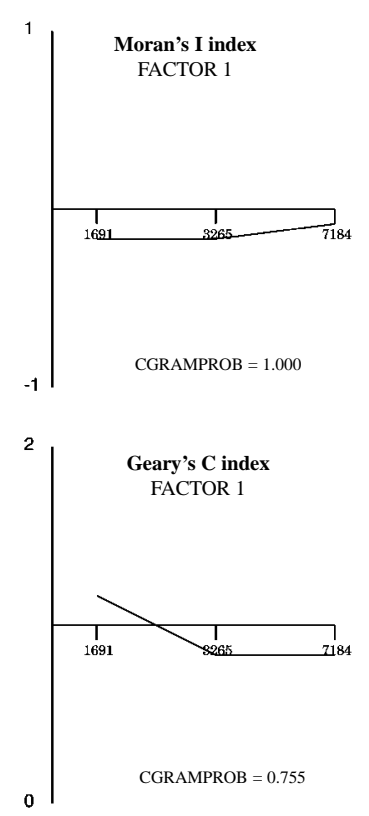

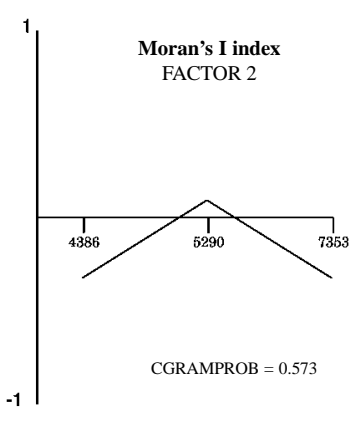

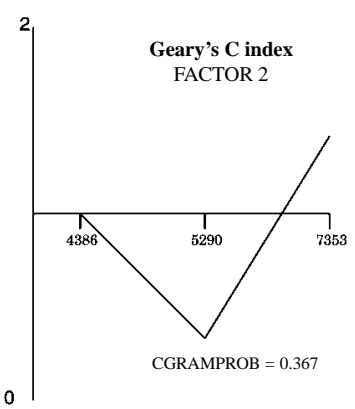

0
Moran's I inde FACTOR 1

CGRAMPROB $=0.832$

Geary's C index FACTOR 1

Subpopulation level

(D) Buenos Aires
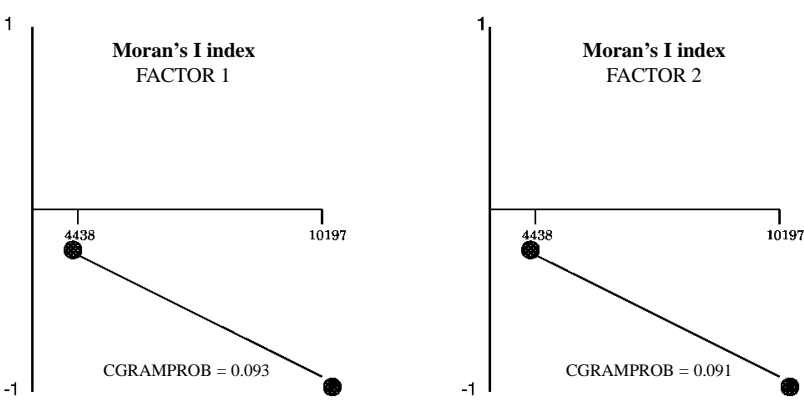

\begin{tabular}{l|l}
-1 & CGRAMPROB $=0.880$
\end{tabular}
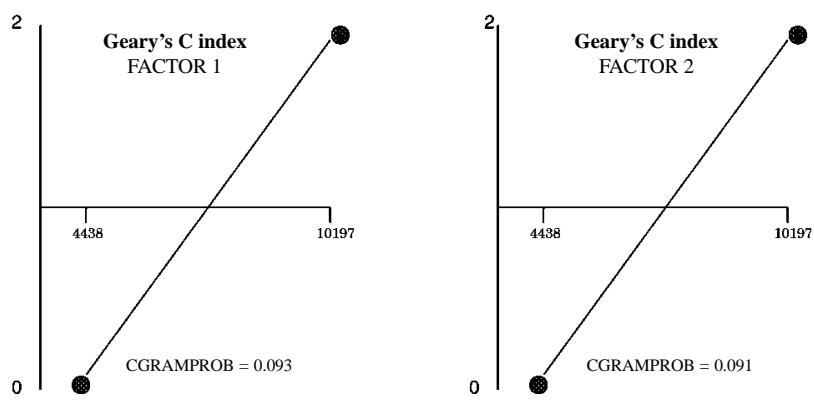

- $\mathrm{P}<0.05$

Figure 2 - Correlograms of the correlation between individual subpopulations of the four cities analyzed and the two first factors (1 and 2) obtained from a Q factorial analysis. The correlograms were obtained with Moran's and Geary's indexes with 3 distance classes (DC) at subpopulation level. (A) Barcelona; (B) Palma majorca; (C) Rimini; (D) Buenos Aires. CGRAMPROB = Overall correlogram probability. 
at the colony level in Barcelona, certain alleles, such as $\mathrm{O}$, $\underline{\underline{\mathrm{t}}}$ and $\underline{1}$, had high scores for the first factor $(-0.729,0.854$, 0.813 , respectively). On the contrary, Buenos Aires had high scores for the first factor with the alleles $\underline{a}, \underline{d}, \underline{1}, \underline{S}$ and $\underline{W}$. Moreover, correlations between the alleles and the first and second factors were different in the same population at the two sampling levels, which demonstrates the importance of chosing a sampling structure representing the most meaningful population unit of observation. Probably the colony level was a more meaningful sampling structure than the rather artificial subpopulation level (e.g., the three alleles more highly correlated with the first factor in Buenos Aires at a colony level were $\underline{a}, \underline{d}$ and $\underline{W}$, while at the subpopulation level were $\underline{\mathrm{d}}, \underline{\mathrm{S}}$ and $\underline{\mathrm{t}})$. Graphical results from the Q factorial analysis (not shown here) illustrated that the relationships between colonies from the different populations are not related with geographical proximity, nor with an isolation-by-distance model.

\section{DISCUSSION}

\section{Genetic heterogeneity and sampling population structure}

The main image revealed by this study is the relative similarity in various aspects between the four cat populations analyzed, regardless of the many differences, in demographic, historical, social, ecological, and temporal parameters in each city studied. A dominant aspect could therefore be the common highly promiscuous reproductive behavior of this species in urban areas (Natoli and De Vito, 1988). The degree of genetic differentiation observed at the colony and subpopulation sampling levels was very small when compared with other species (see Eanes and Koehn, 1978; Wright, 1978; Chesser, 1983). A few small differences between these cities were, however, detected for some of the statistics, and were in some cases correlated with some of the variables mentioned. Some of the differences revealed might not bear any correlation with the variables considered here, such as the distribution and frequency of food sources such as rubbish bins on the streets, and the availability of places of refuge for the animals.

A significant degree of heterogeneity of certain alleles was observed in these populations. At the colony sampling level, the degrees of genetic heterogeneity were undistinguishable between the cities studied. On the contrary, at the subpopulation sampling level, significant differences were found between the cities, for the statistics such as $\mathrm{F}_{\mathrm{ST}}$ or $\mathrm{G}_{\mathrm{ST}}$. Barcelona presented the lowest genetic differentiation at this level. Rimini and Buenos Aires had a similar degree of internal genetic differentiation, while Palma Majorca is slightly more differentiated significantly. The sample size per colony was relatively similar for the four populations, but the sample size of the subpopulations was considerably more heterogeneous from popula-
Table V - Correlation coefficients of seven morphological alleles of Felis catus in the cat colonies and subpopulations studied with the significant first axes (two or three) from an R factorial analysis. Results shown were obtained from the correlation matrix and the iterative principal factor. FACT $=$ Factorial axes. $\mathrm{O}=$ orange $; \mathrm{a}=$ non-agouti $; \mathrm{t}^{\mathrm{b}}=$ blotched tabby; $\mathrm{d}=$ dilution; 1 = long hair; $\mathrm{S}=$ white spotting; $\mathrm{W}=$ dominant white.

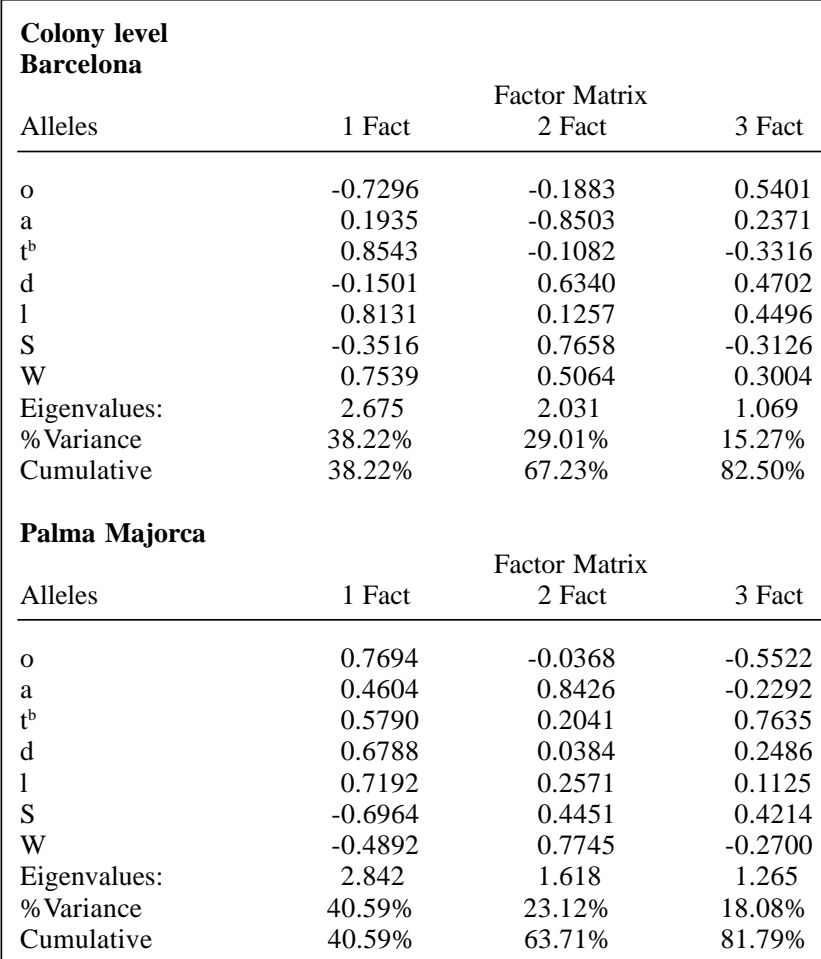

Rimini

\begin{tabular}{|c|c|c|c|}
\hline \multirow{2}{*}{ Alleles } & \multicolumn{2}{|c|}{ Factor Matrix } & \\
\hline & 1 Fact & 2 Fact & \\
\hline o & 0.5525 & -0.6380 & \\
\hline $\mathrm{a}$ & 0.5688 & -0.4519 & \\
\hline$t^{b}$ & -0.8072 & -0.3933 & \\
\hline $\mathrm{d}$ & 0.6342 & 0.6232 & \\
\hline 1 & -0.7673 & 0.2798 & \\
\hline $\mathrm{S}$ & 0.5850 & 0.7139 & \\
\hline W & -0.5493 & 0.5573 & \\
\hline Eigenvalues: & 2.915 & 2.053 & \\
\hline$\%$ Variance & $41.65 \%$ & $29.33 \%$ & \\
\hline Cumulative & $41.65 \%$ & $70.97 \%$ & \\
\hline \multicolumn{4}{|l|}{ Buenos Aires } \\
\hline & & Factor Matrix & \\
\hline Alleles & 1 Fact & 2 Fact & 3 Fact \\
\hline o & 0.5200 & -0.7945 & -0.2362 \\
\hline a & 0.8718 & 0.0810 & 0.2780 \\
\hline $\mathrm{t}^{\mathrm{b}}$ & -0.2235 & -0.8292 & 0.4101 \\
\hline $\mathrm{d}$ & 0.8113 & 0.4332 & 0.2432 \\
\hline 1 & 0.6055 & 0.1807 & -0.7474 \\
\hline $\mathrm{S}$ & 0.6380 & -0.5768 & -0.2125 \\
\hline W & 0.7946 & 0.0810 & 0.4568 \\
\hline Eigenvalues: & 3.144 & 1.885 & 1.173 \\
\hline$\%$ Variance & $44.91 \%$ & $26.93 \%$ & $16.75 \%$ \\
\hline Cumulative & $44.91 \%$ & $71.84 \%$ & $88.60 \%$ \\
\hline
\end{tabular}

Continued on next page 
Table V - Continued

\begin{tabular}{|c|c|c|c|}
\hline \multicolumn{4}{|c|}{$\begin{array}{l}\text { Subpopulation level } \\
\text { Barcelona }\end{array}$} \\
\hline Alleles & 1 Fact & 2 Fact & \\
\hline o & 0.9516 & 0.2291 & \\
\hline $\mathrm{a}$ & 0.9667 & 0.1689 & \\
\hline$t^{b}$ & 0.2222 & 0.9533 & \\
\hline $\mathrm{d}$ & -0.8872 & 0.1157 & \\
\hline 1 & 0.7795 & -0.6066 & \\
\hline $\mathrm{S}$ & -0.8989 & 0.1845 & \\
\hline W & 0.9314 & 0.1592 & \\
\hline Eigenvalies: & 4.960 & 1.431 & \\
\hline$\%$ Variance & $70.85 \%$ & $20.44 \%$ & \\
\hline Cumulative & $70.85 \%$ & $91.29 \%$ & \\
\hline \multicolumn{4}{|c|}{ Palma Majorca } \\
\hline Alleles & 1 Fact & $\begin{array}{c}\text { ctorial Ma } \\
2 \text { Fact }\end{array}$ & 3 Fact \\
\hline o & 0.3655 & -0.6583 & 0.0331 \\
\hline $\mathrm{a}$ & -0.8986 & 0.0942 & 0.2168 \\
\hline $\mathrm{t}^{\mathrm{b}}$ & 0.2585 & 0.8762 & 0.3194 \\
\hline $\mathrm{d}$ & 0.5478 & 0.0264 & 0.8246 \\
\hline 1 & 0.1319 & 0.6235 & -0.6617 \\
\hline $\mathrm{S}$ & -0.8503 & 0.3774 & 0.3038 \\
\hline W & -0.9145 & -0.3532 & 0.0066 \\
\hline Eigenvalues: & 2.885 & 1.867 & 1.360 \\
\hline$\%$ Variance & $41.21 \%$ & $26.67 \%$ & $19.43 \%$ \\
\hline Cumulative & $41.21 \%$ & $67.88 \%$ & $87.31 \%$ \\
\hline \multicolumn{4}{|l|}{ Rimini } \\
\hline & Facto & trix & \\
\hline Alleles & 1 Fact & 2 Fact & \\
\hline o & -0.9343 & 0.0636 & \\
\hline $\mathrm{a}$ & -0.9017 & 0.2197 & \\
\hline $\mathrm{t}^{\mathrm{b}}$ & -0.0129 & -0.9106 & \\
\hline $\mathrm{d}$ & 0.8002 & 0.0644 & \\
\hline 1 & 0.7513 & -0.5504 & \\
\hline $\mathrm{S}$ & 0.6758 & 0.6796 & \\
\hline W & 0.9324 & 0.1592 & \\
\hline Eigenvalues: & 4.217 & 1.676 & \\
\hline$\%$ Variance & $60.24 \%$ & $23.94 \%$ & \\
\hline Cumulative & $60.24 \%$ & $84.18 \%$ & \\
\hline \multicolumn{4}{|l|}{ Buenos Aires } \\
\hline & & ctorial Ma & \\
\hline Alleles & 1 Fact & 2 Fact & 3 Fact \\
\hline o & 0.1610 & 0.5529 & 0.8176 \\
\hline $\mathrm{a}$ & 0.8820 & 0.4671 & 0.0622 \\
\hline$t^{b}$ & -0.8304 & 0.5060 & 0.2330 \\
\hline $\mathrm{d}$ & 0.9956 & 0.0937 & 0.0023 \\
\hline 1 & 0.5239 & -0.7162 & 0.4610 \\
\hline $\mathrm{S}$ & 0.9780 & -0.1942 & 0.0756 \\
\hline W & 0.6912 & 0.5657 & -0.4496 \\
\hline Eigenvalues: & 4.194 & 1.659 & 1.147 \\
\hline$\%$ Variance & $59.91 \%$ & $23.71 \%$ & $16.39 \%$ \\
\hline Cumulative & $59.91 \%$ & $83.61 \%$ & $100 \%$ \\
\hline
\end{tabular}

tion to population. The latter was highly dependent on the sampling scheme, since the criterium for a subpopulation to be considered as such relied solely on geographical (neighbor) location. This effect was not present at the colony level. For instance, the subpopulation level resulted in a big difference in average sample size per subpopulation, 141 for Barcelona and 77 for Rimini, while the aver- age sample size per colony was 64 and 47, respectively, for these populations. This effect should be the result of the significant negative correlation between sample size and degree of differentiation at the subpopulation level. The regression equations between the average geographical surface and the $\mathrm{G}_{\mathrm{ST}}$ values confirmed a negative correlation between the geographical size of the subpopulation and the genetic heterogeneity internal to them. This association was not present at the colony sampling level. This demonstrates the importance of sampling at various levels within a population.

\section{Spatial autocorrelation analysis}

The spatial autocorrelation analysis did not reveal the presence of a clear genetic structure in the cat populations studied. The absence of significant spatial patterns, and the fact that many variables generated different correlograms, could be generally explained as we know that these populations are quite close to panmixia, and have had a high degree of gene flow in different epochs, rates, and directions, for each of the variables studied, at least at the two sampling levels used in this work. An alternative explanation would be the existence of some form of balance, or unifying selection, affecting the majority of the genetic variables studied here. Nevertheless, when Epperson (1990) used computer simulations including uniform spatial selection in the spatial autocorrelation analysis, he observed that the presence of a weak uniform selection $(\mathrm{s}=0.01)$ reduced, but did not eliminate, the local structure of populations with an effective size as small as 9. However, this explanation is unlikely to have had an effect simultaneously on the majority of the loci studied. The absence of spatial structure is therefore more easily explained as being due to extensive gene flow.

When the results of correlations between the localities and the first and second factors submitted to spatial autocorrelation analysis were analyzed, it was found that only the population of Buenos Aires had a statistically significant pattern at the subpopulation sampling level. There was a tendency for genetic similarity to decrease as distance increased in these factors. This was not observed in the three European populations.

One more aspect to discuss are the differences found in the autocorrelation coefficients of the first distance class of the populations studied. More negative autocorrelation coefficient values were found in Barcelona and Rimini for $1 \mathrm{DC}$, the average correlograms, and the autocorrelation analysis of locality correlations, with the first two factors, than was expected for the expected absolute absence of autocorrelation. On the other hand, Buenos Aires showed positive autocorrelation coefficients. Some were significant in $1 \mathrm{DC}$ of the variables studied. The existence of these negative values in 1 DC in Rimini and especially in Barcelona can be explained, since an optimal breeding distance from the point of birth should have 
been developed (maximum genetic diversity in short distances). Gene flow and assortment between cats separated by some distance from their places of origin could maximize fertility and provide greater possibilities for the survival of the progeny (patterns of "leapfrog" gene flow; Waser, 1987). In Barcelona, these phenomena may have developed more strongly than in the other populations, because this population is older and has had more time for these phenomena to develop, or because it has different historical, ecological or demographic characteristics. We must remember that the effect of gene flow tends to accumulate through generations, therefore allowing for a spatial structure to become more defined on a scale that is greater than the individual dispersion (Slatkin, 1978; Barbujani, 1988). In contrast, in Buenos Aires the positive 1 DC coefficients could show the existence of patches. The short time that this population has had to homogenize their patterns of allele frequencies, and ecological or historical factors may explain the differences observed between some of the correlograms obtained for areas of Buenos Aires and the remaining populations.

\section{CONCLUSIONS}

1) Independent of the microgeographical level chosen (colony or subpopulation), the cat populations analyzed are relatively non-heterogeneous, and probably in panmixia. 2) The colony level did not show differences between the values of heterogeneity $\left(\mathrm{F}_{\mathrm{ST}}\right.$ and $\left.\mathrm{G}_{\mathrm{ST}}\right)$ statistics for the four populations analyzed. In contrast, the subpopulation level showed significant differences for these statistics between the four populations. Barcelona was significantly more homogeneous than Palma Majorca. 3) At the colony level no significant correlations were found between the degree of genic differentiation and demographic size. At the subpopulation level instead, significant correlations were detected with the sample size variables. 4) The expected mean heterozygosity and the HardyWeinberg statistics were similar in the populations studied, independent of the sampling microgeographic level chosen. 5) A spatial autocorrelation analysis did not detect any significant spatial trend at a subpopulation level in the four populations studied, with some exceptions in the Buenos Aires population, when the correlation between subpopulations with the first and second factors of the factorial analysis were submitted to spatial autocorrelation. There were no significant differences between the spatial autocorrelation analysis applied at a colony and subpopulation sampling levels. 6) The Barcelona population showed a more similar spatial pattern between the correlograms of the seven loci analyzed than the other populations. This could be explained because it is the most ancient populations studied, or because it has either a higher or constant gene flow, affecting all loci analyzed in the same way. 7) The $\mathrm{R}$ factorial analysis showed that in each city the relationships between the seven genetic variables and the principal factors were different. This is related to the non-existence of systematic selection for these traits in the cities studied. 8) The correlations between the alleles and the first and second factors were different in the same population at both sampling levels based on an $\mathrm{R}$ factorial analysis. 9) The correlations between colonies and subpopulations with the first factors from a $\mathrm{Q}$ factor analysis showed that the correlations with the first factor were very high and homogeneous, and could indicate a high degree of gene flow, or other homogenizing events. Correlations with the secod factor were much less important and could suggest residual stochastic events. 10) The correct choice of the sampling microgeographic level is fundamental in order to arrive to accurate interpretations and comparisons from a population genetic point of view.

\section{ACKNOWLEDGMENTS}

The author is grateful to many people for their contributions towards the realization of this work, either in logistic or material terms. Amongst them and foremost, Drs. A. Sanjuan (Vigo, Spain), A.T. Lloyd (Dublin, Republic of Ireland), K.K. Klein (Mankato, Minnesota, USA), P. Dreux (Paris, France), R. Robinson (London, Great Britain), A. Kajon (Buenos Aires and Georgia, Argentina and USA, respectively), and especially to Diana Alvarez and Lulu Angarita (Bogota, DC., Colombia). The author is very grateful for the corrections and comments of the referees. They were very useful.

This work was partially supported by the grant Convenio No. 139-94 and No. 140-96 (Decreto 1742 de 1994) between Colciencias and the author (M. Ruiz-Garcia). This work is in memoriam of Dr. Roy Robinson, who was both one of the most important specialist in mammal coat color geneticists and an excellent person.

\section{RESUMO}

Os marcadores fenotípicos cor da pelagem, padrão e comprimento dos pelos de populações naturais de gato doméstico de quatro cidades (Barcelona, Catalunha; Palma Majorca, Ilhas Baleares; Rimini, Itália, e Buenos Aires, Argentina) foram estudados em nível microgeográfico. Várias técnicas de genética de populações revelaram que o grau de diferenciação genética entre populações de Felis catus nessas cidades é relativamente baixo, quando comparado com aquele encontrado entre populações de outros mamíferos. Dois diferentes níveis de amostragem foram usados. Um foi o de colônias "naturais" de famílias de gatos vivendo juntas em pontos específicos das cidades e o outro foi de subpopulações "artificiais", ou grupos de colônias, habitando o mesmo bairro de uma cidade. Para os dois níveis de amostragem, alguns dos resultados foram idênticos: 1) pouca heterogeneidade gênica, 2) existência de panmixia, 3) níveis semelhantes de heterozigosidade esperada em todas as populações analisadas, 4) ausência de autocorrelação espacial, com certa diferenciação na população de Buenos Aires comparada às outras, e 5) correlações muito altas entre colônias e subpopulações com os primeiros fatores de uma análise de fator Q. Não obstante, outros dados estatísticos de genética de população mostraram-se muito afetados pela escolha diferencial do nível de amostragem. Foi o caso de: 1) a quantidade de heterogeneidade 
dos dados estatísticos $F_{S T}$ e $G_{S T}$ entre as cidades, que foi maior no nível de subpopulação do que no nível de colônia; 2) a existência de correlações entre os dados estatísticos de diferenciação gênica e variáveis de tamanho no nível subpopulacional, mas não no nível de colônias, e 3) a relação entre as variáveis genéticas e os principais fatores da análise fatorial $\mathrm{R}$. Isto sugere que se deve tomar cuidado ao escolher a unidade de amostragem, para que as inferências a respeito da genética de população sejam válidas a nível microgeográfico.

\section{REFERENCES}

Bailey, N.T.J. (1951). On estimating the size of mobile populations from recapture data. Biometrica 38: 293-306.

Bailey, N.T.J. (1952). Improvements in the interpretation of recapture data. J. Anim. Ecol. 18: 697-702.

Barbujani, G. (1988). Diversity of some gene frequencies in European and Asian populations. IV. Genetic population structure assessed by the variogram. Ann. Hum. Genet. 52: 215-255.

Cattell, R.B. (1966). The scree test for the number of factors. Multivar. Behav. Res. 1: 245-276.

Caughley, G. (1977). Sampling in aerial survey. J. Wildl. Manage. 41: 605615.

Chapman, D.G. (1951). Some properties of the hypergeometric distribution with applications to zoological sample censuses. Univ. Calif. Public. Stat. 1: 131-160.

Chesser, R.K. (1983). Genetic variability within and among populations of black tailed prairie dog. Evolution 39: 1223-1235.

Darroch, J.N. (1958). The multiple-recapture census: I. Estimation of a closed population. Biometrika 45: 343-359.

Eanes, W.F. and Koehn, R.K. (1978). An analysis of genetic structure in the monarch butterfly, Danaus plexipus. Evolution 32: 784-797.

Epperson, B.K. (1990). Spatial autocorrelation of genotypes under directional selection. Genetics 124: 757-771.

Gabriel, K.R. and Sokal, R.R. (1969). A new statistical approach to geographic variation analysis. Syst. Zool. 18: 259-278.

Harris, R.J. (1985). A Primer of Multivariate Statistics. Academic Press, Inc., Orlando, Florida.

Kaiser, H.F. (1960). The application of electronic computers to factor analysis. Educ. Psychol. Measur. 20: 141-151.

Liberg, O. and Sandell, M. (1988). Spatial organisation and reproductive tactics in the domestic cat and other felids. In: The Domestic Cat, the Biology of its Behaviour (Turner, D.C. and Batenson, P., eds.). Cambridge University Press, Cambridge, pp. 83-98.

Maxwell, A.E. (1977). Multivariate Analysis in Behavioural Research. Chapman and Hall, London.

Natoli, E. and De Vito, E. (1988). The mating system of feral cats living in a group. In: The Domestic Cat, the Biology of its Behaviour (Turner, D.C. and Batenson, P., eds.). Cambridge University Press, Cambridge, pp. 99-108.

Nei, M. (1973). Analysis of gene diversity in subdivided populations. Proc. Nat. Acad. Scien. USA 70: 3321-3323.

Nei, M. (1978). Estimation of average heterozygosity and genetic distance from a small number of individuals. Genetics 96: 583-590.

Nygren, J. and Rasmusson, M. (1980). Allozyme variation in natural populations of field voles (Microtis agrestis L.). I. Survey of the "semistable" population in southern Sweden. Hereditas 92: 65-72.

Oden, N. (1984). Assessing the significance of a spatial correlogram. Geogr. Anal. 16: 1-16.

Pollock, K.H. (1981). Capture-recapture models: a review of current method assumptions and experimental design. Stud. Avian Biol. 6: 426-435.

Robinson, R. (1972). Mutant gene frequencies in cats of Cyprus. Theor. Appl. Genet. 42: 293-296.

Robinson, R. (1977). Genetic for Cat Breeders. Pergamon Press, Oxford.

Robinson, R. and Silson, M. (1969). Mutant allele frequencies in cats of southern England. Theor. Appl. Genet. 39: 326-329.

Ruiz-Garcia, M. (1988). Frecuencias alélicas mutantes en una población de gatos domésticos urbanos (Barcelona) y en una población de gatos rurales (Castelldefels rural) en Cataluña, España. Genét. Ibér. 40: 157-187.

Ruiz-Garcia, M. (1989). The urban effect in two Spanish domestic cat populations. C. Gene. J. 6: 1-26.

Ruiz-Garcia, M. (1991). Más sobre la Genética de Poblaciones de Felis catus en la costa Mediterranea Española: Un analisis de la estructura genética de las poblaciones naturales de gatos. Evol. Biol. 5: 227-283.

Ruiz-Garcia, M. (1993). Analysis of the evolution and genetic diversity within and between Balearic and Iberian cat populations. J. Hered. 84: 173-180.

Ruiz-Garcia, M. (1994). Genetic structure of Marseilles cats: Is there really strong founder effect? Genet. Sel. Evol. 26: 317-331.

Ruiz-Garcia, M. (1997). Genetic relationships among some new cat populations sampled in Europe: a spatial autocorrelation analysis. J. Genet. 76: $1-24$.

Ruiz-Garcia, M. (1998a). Genetic structure and evolution of different cat populations (Felis catus) in Spain, Italy and Argentina at microgeographic level. Acta Theriol. 43: 39-66.

Ruiz-Garcia, M. (1998b). Genetic microstructure in two Spanish cat populations. I: Genic diversity, gene flow and selection. Genet. Sel. Evol. (in press).

Ruiz-Garcia, M. (1998c). Genetic microstructure in two Spanish cat populations. II.: Gametic disequilibrium and spatial autocorrelation. Genet. Sel. Evol. (in press).

Ruiz-Garcia, M. and Jordana, J. (1997a). Spatial genetic structure of the "Gos d'Atura" dog breed in Catalonia (Spain). Braz. J. Genet. 20: 225-236.

Ruiz-Garcia, M. and Jordana, J. (1997b). Spatial genetic structure from blood allozymes in the Pyrenean Brown, a rare cattle breed, in Catalonia (Spain). J. Genet. (in press).

Ruiz-Garcia, M. and Klein, K.K. (1997). Genetic structure of domestic cat populations (Felis catus) at micro and macrogeographical levels: Two examples (Catalonia, Spain, and Upper Mid-Western USA). J. Genet. 76: 99-115.

Searle, A.G. (1949). Gene frequencies in London's cats. J. Genet. 49: 214 220.

Seber, G.A.F. (1982). The Estimation of Animal Abundance and Related Parameters. Griffin \& Co., London.

Slatkin, M. (1978). Spatial patterns in the distribution of polygenic characters. J. Theor. Biol. 70: 213-228.

Sokal, R.R. and Oden, N.L. (1978a). Spatial autocorrelation in biology. 1. Methodology. Biol. J. Linn. Soc. 10: 199-228.

Sokal, R.R. and Oden, N.L. (1978b). Spatial autocorrelation in biology. 2. Some biological implications and four applications of evolutionary and ecological interest. Biol. J. Linn. Soc. 10: 229-249.

Sokal, R.R. and Rohlf, F.J. (1981). Biometry. 2nd edn. Freeman, New York. Southwood, T.R.E. (1978). Ecological Methods. Chapman \& Hall, London.

Tellerias, J.L. (1986). Manual para el Censo de los Vertebrados Terrestres. Ed. Raices, Madrid.

Todd, N.B. (1977). The dynamics of owned domestic cat populations. Carniv. Genet. Newsl. 3: 100-124.

Trexler, J.C. (1988). Hierarchical organization of genetic variation in the sailfin molly, Poecilia latipinna (Pisces:Poeciliidae). Evolution 42: 1006-1017.

Waser, N.M. (1987). Spatial genetic heterogeneity in a population of the montane perennial plant Delphinium nelsonii. Heredity 58: 249-256.

Workman, P.L. and Niswander, J.D. (1970). Population studies on south western Indian Tribes. II. Local genetic differentiation in the Papago. Am. J. Hum. Genet. 22: 24-49.

Wright, S. (1951). The genetical structure of populations. Ann. Euge. 15: 323-354.

Wright, S. (1965). The interpretation of population structure by F-statistics with special regards to systems of mating. Evolution 19: 395-420.

Wright, S. (1969). Evolution and Genetics of Populations. Vol. 2. The theory of Gene Frequencies. University of Chicago Press, Chicago, pp. 511.

Wright, S. (1978). Evolution and Genetics of Populations. Vol. 4. Variability Within and Among Natural Populations. University of Chicago Press, Chicago.

Wright, M. and Walters, S. (1982). El Gato. Ed. Blume, Barcelona. 
